九州大学学術情報リポジトリ

Kyushu University Institutional Repository

\title{
A NEW SPECIES OF THE GENUS TETRAGNATHA (ARANEAE: TETRAGNATHIDAE) FROM TROPICAL ASIA
}

Okuma, Chiyoko

https://doi.org/10.5109/2392

出版情報 : ESAKIA. 14，pp.73-77，1979-11-15. Entomological Laboratory，Faculty of Agriculture， Kyushu University

バージョン :

権利関係 : 


\title{
A NEW SPECIES OF the genUs tetragnatha (ARANEAE: TETRAGNATHIDAE) FROM TROPICAL ASIA*
}

\author{
Chiуoко OKuma \\ Entomological Laboratory, Faculty of Agriculture \\ Kyushu University, Fukuoka 812, Japan
}

\begin{abstract}
A new species, Tetragnatha virescens, is described from Tropical Asia.
\end{abstract}

In this paper a new species Tetragnatha virescens is described from Tropical Asia. The new species was provisionally named Tetragnatha sp. A by Okuma $(1968,1973)$ and has been treated as such in her personal communications.

I wish to express my sincere gratitude to Professor Y. Hirashima and Associate Professor K. Morimoto of Kyushu University for their continuous guidance. I am also much indebted to Professor Emeritus K. Yasumatsu of Kyushu University, Dr. A. Ôtake of Fruit Tree Research Station, Dr. N. Hokyo of Okinawa Prefectural Agricultural Experiment Station and Dr. H. Mita of Central Agricultural Research Institute of Sri Lanka who provided me with valuable specimens for the present study.

\section{Tetragnatha virescens sp. no v.}

Tetragnatha sp. A Okuma. Mushi, 1968, $42(8)$ : 103,112; Okuma, 1973, 47(1):5,8, 11, 12.

Male. Body length, exclusive of chelicerae 5. 9 to $7.8 \mathrm{~mm}$; carapacial length 1.8 to $2.3 \mathrm{~mm}$, width 1.1 to $1.4 \mathrm{~mm}$, abdominal length 4.1 to $5.5 \mathrm{~mm}$, width 0.70 to $1.05 \mathrm{~mm}$.

Eyes. Anterior row of eyes occupying the full width of carapace; posterior row considerabley shorter. Viewed from above, anterior row of eyes gently recurved, posterior row strongly recurved ; viewed in front, anterior row definitely procurved, posterior row straight or slightly recurved; central ocular quadrangle wider behind than in front in ratio of $31: 23$, length about equal to width behind; diameter of each eye is as follows : AME: ALE : PME :

* Contribution from the Entomological Laboratory, Faculty of Agriculture, Kyushu University, Fukuoka (Ser. 3, No. 64). 
PLE $=100: 48: 59: 57 \mu$; AME separated from one another by their diameter, and from ALE about 2 to 2.7 times their diameter; PME separated from one another about 3 to 3.5 times their diameter and is separated from PLE about 2 to 3 times their diameter; lateral eyes separated from one another about 5 to 7 times by diameter of ALE; AME separated from PME by about 1.5 times their diameter; height of clypeus about as long as diameter of AME.

Chelicerae. Length of basal segment 1.0 to $1.4 \mathrm{~mm}$; fang with two inner cusps, the basal one about one-fifth from base; prolateral spur not apically bifid, the "Iarge tooth" present, and these together with a continual small tooth forming a group of three teeth, in addition to each five to seven small teeth on pro- and retromargins of fang groove (Figs. 1-3).

Maxillae. Nearly parallel, longer than lip in ratio of $2.4: 1$, more than 4 times as long as wide at narrowest level.

Lip. Shorter than broad at base in ratio of 3:4; sternal suture nearly straight.

Sternum. Length 0.9 to $1.1 \mathrm{~mm}$, width 0.7 to $0.8 \mathrm{~mm}$; continued between fourth coxae which are separated by about $125 \mu$.

Legs. 1 2-4 3. All legs with spines and hair. Trichobothria on all femora. Relative measurements of legs as follows:

\begin{tabular}{lcccccr} 
& Femora & Pa tellae & Tibiae & Metatarsi & Tarsi & \multicolumn{1}{c}{ Totals } \\
1 & $5.051-0.48$ & $0.88 \pm 0.07$ & $5.37 \pm 0.56$ & $5.11 \pm 0.49$ & $1.33 \pm 0.07$ & $\mathbf{1 7 . 7 0 k \mathbf { . 6 6 }}$ \\
$\mathbf{2}$ & $\mathbf{3 . 6 9 1 f \mathbf { 0 . 3 5 }}$ & $0.71 \pm 0.05$ & $3.44 \pm 0.30$ & $3.29 \pm 0.31$ & $0.93 \pm 0.05$ & $12.05 \pm 1.03$ \\
$\mathbf{3}$ & $1.84 \pm 0.18$ & $\mathbf{0 . 4 5 1 0 . 0 5}$ & $\mathbf{1 . 3 3 i} \mathbf{0 . 1 3}$ & $\mathbf{1 . 3 4 t \mathbf { 0 . 0 9 }}$ & $0.53 \pm 0.04$ & $5.48 \pm 0.45$ \\
$\mathbf{4}$ & $3.88 \pm 0.36$ & $0.56 \pm 0.04$ & $\mathbf{3 . 2 8 t \mathbf { 0 . 3 1 }}$ & $3.09 \pm 0.27$ & $0.76 \pm 0.05$ & $11.56 \pm 0.98$ \\
Palp & $1.08 \pm 0.08$ & $0.28 \pm 0.03$ & $0.31 \pm 0.04$ & $/$ & $0.99 \pm 0.05$ & $2.65 \pm 0.16$
\end{tabular}

Palp. Tibia only slightly longer than patella; paracymbium long, slender, bluntly rounded at its distal end; distal end of conductor and embolus as shown in Figs. 4 and 5.

Abdomen. Long and slender, slightly extended posteriorly to spinnerets.

Color in alcohol. Legs, cephalothorax and mouthparts yellowish brown; abdomen covered with many yellowish silvery spangles and grayish reticulations; venter also covered with yellowish silvery spangles, without a median stripe which is so frequently present in the genus.

Female. Body length, exclusive of chericerae 6.55 to $8.25 \mathrm{~mm}$; carapacial length 1.85 to $2.25 \mathrm{~mm}$, width 1.2 to $1.4 \mathrm{~mm}$; abdominal length 4.6 to $6.0 \mathrm{~mm}$, width 1.0 to $2.0 \mathrm{~mm}$.

Eyes. Essentially as in male (Fig. 6), but each ratio and diameters of eyes somewhat different from male; central ocular quadrangle, slightly wider behind than in front in ratio of $30: 29$; length about equal to width behind; diameter of each eye as follows: AME: ALE : PME : PLE = 103:48: $58: 55 \mu$; AME separated from one another by their diameter, and from ALE slightly 



Figs. 1-9. Tetragnatha virescens sp. nov. 1-3: Right chelicerae of male. 4: Distal end of male conductor and embolus. 5: Male paracymbium. 6: Eye group of female from above. 7: Genital fold of female. 8-9: Right chelicerae of female. 
more than 2 times their diameter; PME separated from one another about 3 times their diameter and is separated from PLE about 2.4 times their diameter; lateral eyes separated from one another by 4.3 times diameter of PLE; AME separated from PME by slightly more than diameter of AME; height of clypeus about 0.75 times as long as diameter of AME.

Chelicerae. Basal segment 0.65 to $0.85 \mathrm{~mm}$ in length, fang without cusps; promargin of fang groove with five to eight teeth; retromargin with four to five teeth (Figs. 8 and 9).

Legs. Essentially as in male. Relative measurements of legs as follows:

\begin{tabular}{|c|c|c|c|c|c|}
\hline & & Femora & Patellae & Metatarsi & Totals \\
\hline 1 & & 4.44 & $.86 \pm 0.06$ 4. $51 \pm 0.37$ & 4. $28 \pm 0.321 .17 \pm 0.05$ & $5 \pm 1.07$ \\
\hline 2 & & 3.1 & $0.70 \pm 0 . \quad 05 \quad 2.86 \pm 0.21$ & $2.76 \pm 0.222 \quad 0.84 \pm 0.05$ & \pm 0.73 \\
\hline 3 & & 1.63 & $0.43 \pm 0.041 .111-0.0$ & $\begin{array}{llll}8 & 1.18 \pm 0.11 & 0.51 \pm 0\end{array}$ & .36 \\
\hline 4 & & 24 & $0.55 \pm 0.05 \quad 2.79 \pm 0 . \quad 22$ & $2.65 \pm 0 . \quad 2 \quad 4 \quad 0.72 \pm 0.05$ & $10.21 \pm 0.76$ \\
\hline & & $0.74 \pm 0.04$ & $0.23 \pm 0$ & $/ 0.74 \pm 0$ & $2.20 \pm 0.13$ \\
\hline
\end{tabular}

Color in alcohol. Essentially as in male.

Distribution: Sri Lanka, Thailand, Malaysia, Indonesia and Philippines.

Type material: Holotype $\sigma^{\top}$ (Type No. 2155, Kyushu Univ.), Bangkhen, Thailand, 12. XI. 1970, C. Okuma leg. Paratopotypes: 12 乃 8 and 15 우우, same data as holotype. Paratypes : Thailand, 11 ऊో an $\sigma^{-} 0^{-}$, Rangsit, 7. XI. 1966, C.

Table 1. Measurements of Tetragnatha virescens sp. nov.

\begin{tabular}{|c|c|c|c|c|}
\hline $\begin{array}{c}\text { Sex } \\
\text { No. of specimens } \\
\text { examined }\end{array}$ & \multicolumn{2}{|c|}{$\begin{array}{l}\text { 古 } \\
10\end{array}$} & \multicolumn{2}{|c|}{ 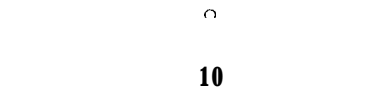 } \\
\hline Body length (mm) & $\begin{array}{r}\text { mean } \pm \text { s. d. } \\
6.63 \pm 0.55\end{array}$ & $\begin{array}{c}\text { (range) } \\
(5.90-7.80)\end{array}$ & $\begin{array}{r}\text { mean-t s. d. } \\
7.2410 .60\end{array}$ & $\begin{array}{l}\text { (range) } \\
(6.55-8.25)\end{array}$ \\
\hline $\begin{array}{l}\text { Carapace, length } \\
\text { width }\end{array}$ & $\begin{array}{l}2.06 \pm 0.14 \\
1.25 \pm 0.09\end{array}$ & $\begin{array}{l}(1.80-2.30) \\
(1.10-1.40)\end{array}$ & $\begin{array}{l}2.04 \pm 0.13 \\
1.30 \pm 0.06\end{array}$ & $\begin{array}{l}(1.85-2.25) \\
(1.20-1.40)\end{array}$ \\
\hline $\begin{array}{l}\text { Sternum, length } \\
\text { width }\end{array}$ & $\begin{array}{l}1.01 \pm 0.06 \\
0.73 \pm 0.04\end{array}$ & $\begin{array}{l}(0.90-1.10) \\
(0.70-0.80)\end{array}$ & $\begin{array}{l}1.00 \pm 0.05 \\
0.74 \pm 0.05\end{array}$ & $\begin{array}{l}(0.90-1.10) \\
(0.70-0.80)\end{array}$ \\
\hline $\begin{array}{r}\text { Abdomen, length } \\
\text { width }\end{array}$ & $\begin{array}{l}4.57 \pm 0.44 \\
0.85 \pm 0.09\end{array}$ & $\begin{array}{l}(4.10-5.50) \\
(0.70-1.05)\end{array}$ & $\begin{array}{l}5.20 \pm 0.53 \\
1.14 \pm 0.11\end{array}$ & $\begin{array}{l}(4.60-6.00) \\
(1.00-1.30)\end{array}$ \\
\hline $\begin{array}{l}\text { Chelicerae, length } \\
\text { Maxilla, length }(\mu) \\
\text { width }\end{array}$ & $\begin{array}{c}1.22 \pm 0.11 \\
683 \mathrm{k} 51.5 \\
170 \pm 8.8\end{array}$ & $\begin{array}{c}(1.00-1.40) \\
(600-775) \\
(150-175)\end{array}$ & $\begin{array}{r}0.74 \pm 0.06 \\
640 \pm 55.0 \\
208 \text {-t } 14.8\end{array}$ & $\begin{array}{c}(0.65-0.85) \\
(575-725) \\
(188-238)\end{array}$ \\
\hline $\begin{array}{l}\text { Lip, length } \\
\text { width (base) }\end{array}$ & $\begin{array}{l}290 \mathrm{rfi} 22.5 \\
393 \pm 16.8\end{array}$ & $\begin{array}{l}(250-325) \\
(375-425)\end{array}$ & $\begin{array}{l}285 \mathrm{i} 20.0 \\
403 \pm 25.0\end{array}$ & $\begin{array}{l}(250-313) \\
(375-450)\end{array}$ \\
\hline Eye diameter & & & & \\
\hline $\mathrm{AME}$ & $100 \pm 4.5$ & (95-1 13) & $103 \pm 4.0$ & $(100-113)$ \\
\hline A L E & $48 \pm 4.0$ & $(38-50)$ & $48 \pm 2.5$ & $(45-50)$ \\
\hline PME & $59 \mathrm{t} 3.8$ & $(55-63)$ & $58 \pm 6.3$ & $(50-70)$ \\
\hline P L E & $57 \pm 3.0$ & $(55-63)$ & $55 \pm 4.0$ & $(59-63)$ \\
\hline
\end{tabular}


Okuma leg. ; 10 §ð $\delta^{7}$ and 10 우우, Ubol Rochathani, 29. X. 1976, K. Yasumatsu leg. ; Sri Lanka, 6 ॠ $\delta^{\top}$ and 10 우우, Gannoruwa, Peradenia, H. Mita leg. ; West Malaysia, $4 \delta$ and 6 우우 Coastal Plain, 5. II. 1976, Ôtake et Hokyo leg. ; Cental Java,

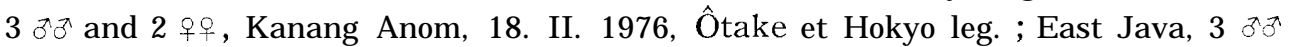
and 3 우우, Rogo Jampi, 21. II. 1976, Ôtake et Hokyo leg.

TYPE DEPOSITORY : The holotype is preserved in the collection of the Entomological Laboratory, Faculty of Agriculture, Kyushu University.

Diagnosis: This new species is related to T.vermiformis Emerton 1884, from U.S.A. but is separable from the latter by the body pale and silky (much darker in vermiformis) and the male cheliceral fang with two inner cusps, the basal one about one-fifth from base (male cheliceral fang with only one inner cusp in vermiformis). The arrangement of the male cheliceral teeth is also different.

Note: This new species is common in the paddy field of Tropical Asia, and the body is light green in color similar to the leaf of rice plant in life.

\section{References}

Chickering, Arthur M. 1957. The genus Tetragnatha (Araneae, Argiopidae) in Panama. Bull. Mus. Comp. Zool. Harv., 116: 301-354.

Okuma, C. 1968. Preliminary survey on the spider-fauna of the paddy fields in Thailand. Mushi, $42: 89-118$.

- 1973. Second report on the spider-fauna of the paddy fields in Thailand. Mushi, 47: $l-17$.

Seeley, R. M. 1928. Revision of the spider genus Tetragnatha. Bull. New York State Mus., 278 : 99-150. 